\title{
A Case Study of Process Engineering of OPERATIONS IN WORKING SITES THROUgh DATA MINING AND AUGMENTED REALITY
}

\author{
Alessandro Massaro ${ }^{1, *}$, Angelo Galiano ${ }^{1}$, Antonio Mustich ${ }^{1}$, Daniele Convertini ${ }^{1}$, \\ VincenzoMaritati ${ }^{1}$, Antonia Colonna ${ }^{1}$, Nicola Savino ${ }^{1}$, Angela Pace ${ }^{2}$, Leo \\ Iaquinta $^{2}$ \\ ${ }^{1}$ Dyrecta Lab, IT Research Laboratory, Via Vescovo Simplicio, 45, 70014 Conversano \\ (BA), Italy. \\ ${ }^{2}$ SO.CO.IN. SYSTEM srl, Contrada Grave- 70015- Noci (BA), Italy
}

\begin{abstract}
In this paper is analyzed the design of a software platform concerning a case study of process engineering involving the simultaneous adoption of data digitation, Data Mining -DM-processing, and Augmented Reality -AR-. Specifically is discussed the platform design able to upgrade the Knowledge Base -KBenabling production process optimizations in working sites. The KB is gained by following 'Frascati' research guidelines addressing the possible ways to achieve the Knowledge Gain -KG-. The technologies such as AR and data entry mobile app are tailored in order to apply innovative data mining algorithms. In the first part of the paper is commented the preliminary project specifications, besides, in the second part, are shown the use cases, the unified modeling language -UML- models, and the mobile app mockups enabling KG. The proposed work discusses preliminary results of an industry project.
\end{abstract}

\section{KEYWORDS}

Frascati Guideline, Knowledge Base Gain, Data Mining, Augmented Reality.

\section{INTRODUCTION}

In [1] some researchers highlight the importance of information digitization processes in different sectors which allow to search/access easier data and information, to reduce human resources costs, to replicate easily data (data preservation), and to organize information. The digitized data allow also to automate the processes [2]. Process automation is a topic of significant importance for the speeding up and optimization of activities performance, and in general for the optimal execution of the works [3]. In models oriented on data quality [4], the correct execution of a machining process and data entry automation can optimize industry performances. The main Knowledge Base -KB- of the information is into the enterprise information systems (Enterprise Resource Planning -ERP- database) representing the "heart" of the information of a company. The data acquisition procedure is important for the creation of Business Intelligence -BI- model [5], able to manage data into several levels such as: 
- Data entry system;

- Data governance;

- Data integration;

- Data mastering;

- Analytics and Reporting.

The digitalization process could have an impact in the business causing changes for companies due to the adoption of digital technologies in the organization or in the operation environment [6]. The digitalization process is therefore important both for company production [7], and for industry perspectives [8]. From the scientific point of view, BI is closely related to the digital transformation, to data mining [9]-[12], and to knowledge management [13]-[14]. Companies at present must establish new management procedures to govern complex transformations. To do this, it is also necessary to define appropriate strategies for implementing the digital transformation [10]-[11]. These strategies must be consistent, so it becomes necessary in the first analysis to remap all current industry processes before defining new procedures related to the digitization and automation of the data flow deriving from the technological innovation. The BI is also closely linked to the life time of a product, of a service or of any activities [15] suitable to formulate new strategies. A digital tool to support the company's business strategy [16] is the Augmented Reality -AR- viewer [17]-[19], which can be used both for staff training and for the interaction with workers. In this context, this tool can introduce new processes concerning installation, configuration and maintenance of equipment and tools, thus providing a real time support for a worker developing activities into a working site. Following a specific case of study and the preliminary state of the art, has been designed a software platform including the digitization process, innovative algorithms, and the AR for enabling an upgrade of production processes of a company working in the realization of electrical, electronic, energy systems and radio bridges. An important part of the activity is in the management of activities which requires innovative procedures and new processes to speed up operations, to make services more efficient, and to formulate BI strategies. In this context, is carry out a research allowing the acquisition of new knowledge enabling new processes and services. To do this it becomes necessary to: i) map the actual 'AS IS' processes; ii) digitize other data and information relevant for various operations, enter data into a database system, and process data in an appropriate manner; iii) improve knowledge gain by adopting data mining algorithms and AR technology. This requires process engineering that includes the remapping of the operating procedures, the information digitalization by implementing a suitable data entry technology, the integration of the ERP database into a new information system managed by a software prototype platform, the data processing using advanced algorithms, and the integration of technologies designed to speed up/optimize performance also adopting online interactivity. All the listed activities are important in order to improve the $\mathrm{KB}$ allowing to expand the knowledge. Following 'Frascati' research guidelines [20], the Knowledge Gain -KG- represents the main goal of the research. KG is a topic of the industry research which can be improved by all elements able to provide new knowledge such as process engineering, data entry supporting process mapping and data mining -DMprocessing [21]-[22]. Following the topics of the state of the art and the industry project goal has been structured the proposed paper as follows:

- process mapping of "AS IS" production process able to check and to improve the KB of the case of study;

- definition of the main project specifications by addressing the research in the KG development;

- discussion of the cases uses involving innovative data mining algorithms enabling KG;

- design of the new data entry system embedding AR technology and enabling knowledge gain;

- conclusions describing all elements improving the information system. 


\section{Process Mapping AND KNOWledge BASE}

In order to define the project specifications has been mapped the actual production process of the analyzed case of study ('AS IS' processes). The SO.CO.IN SYSTEM s.r.l. industry works mainly in the realization of electrical, electronic, energy systems and radio bridges. An important part of the activity is then the management of jobs, which, to date, requires innovative procedures to speed up operations, to make services more efficient, and to be able to apply BI operations. In Fig. 1 is illustrated the main production process of the industry.

\section{PRODUCTION PROCESS}
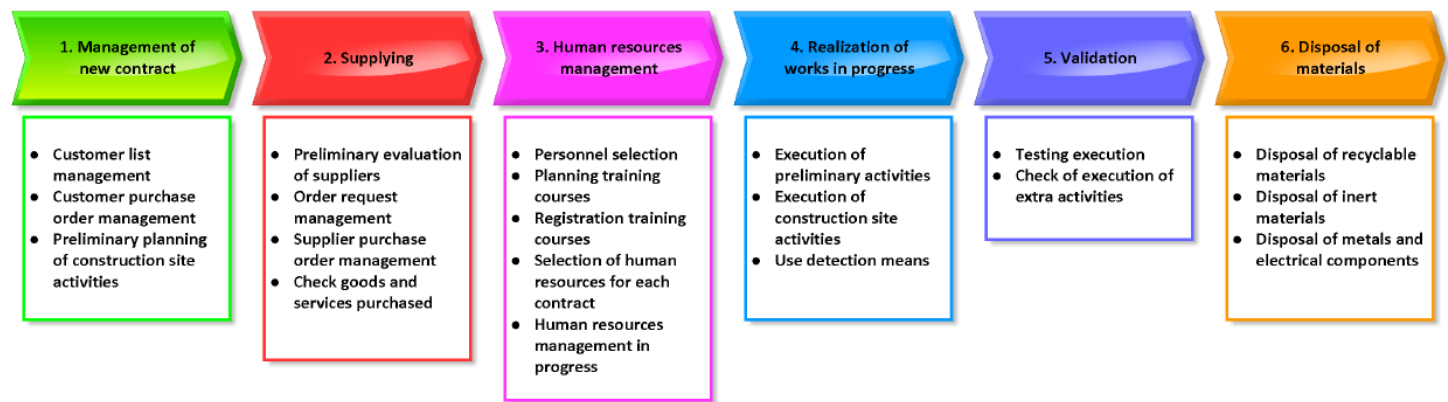

Figure 1. Main production process of the case of study ('AS IS' mapping).

In the workflow of Fig. 1 it is clear how the main process is structured in preparatory steps as follows:

- New contract management;

- Supplying;

- Human Resources Management;

- Realization of works in progress;

- Validation;

- Disposal of materials.

The knowledge base -KB- of the industry is in the formulation of each sub-processes indicated in Fig. 1. In Appendix are reported some mapped sub-processes such as human resources and vehicle control, useful to understand how knowledge base could be improved. We observe that 'AS IS' process mapping are fundamental in order to digitize production process information but do not represent the KG which can be performed by applying data mining algorithms. The whole production process should be implemented into a properly structured Business Process Model BPM-

\section{Preliminary Project Design and Knowledge Gain}

In this section we describe the main project idea derived from the carried out feasibility studies which define the general design specifications. Specifically, the research project is focused on the engineering processes related to the operational interventions of SO.CO.IN SYSTEM s.r.l. through the digitization of data, and the use of augmented reality as a tool to support the execution of the various activities of the operators. The project specifications are classified in the following three main modules: 
- Data entry module (module 1): through this module will be designed frameworks compatible with the company's production processes, thus facilitating the digitization data procedure (data entry); in this context, a mobile APP (IoS / Android) will embed the different data entry frameworks; the operator will enter operational data via tablet or smartphone; data will be stored into a database and will be processed to speed up and optimize all 'AS IS' production processes; the data will be processed using data mining algorithms suitable for data clustering and data classification of all the digitized information, carrying out predictive evaluations and graphical reporting of the processing results (graphic dashboards).

- Teleservice Augmented Reality -AR- communication module (module 2): through this module it will be possible to communicate in bidirectional mode and online with the worker present on site; a remote online viewer (expert) will view in real time what the worker is observing on site, and, at the same time, he will provide useful information/instructions for the type of work to be carried out (in this way even non-trained operators can carry out tasks not aligned with his experience); specifically, the AR facility will be used to:

- train field personnel through e-learning and remote support;

- provide support for processing/maintenance using AR manuals;

- provide a further tool for data entry process.

- Management system integration module (module 3): a more profiled management software will be implemented for the production process mapping, integrating the ERP database.

The combined use of the three technological modules will therefore serve to speed up the work and to automate all the operating procedures in order to also carry out statistical analyzes and forecast calculations on the various types of activities to be performed. Furthermore, the combined use of AR with data digitization will redefine the new business processes by reengineering all the procedures. The three modules are parts of a software platform enabling KG.

In Fig. 2 we report a functional scheme of the proposed research project.

Socoin System Digitalization/AR Improvements

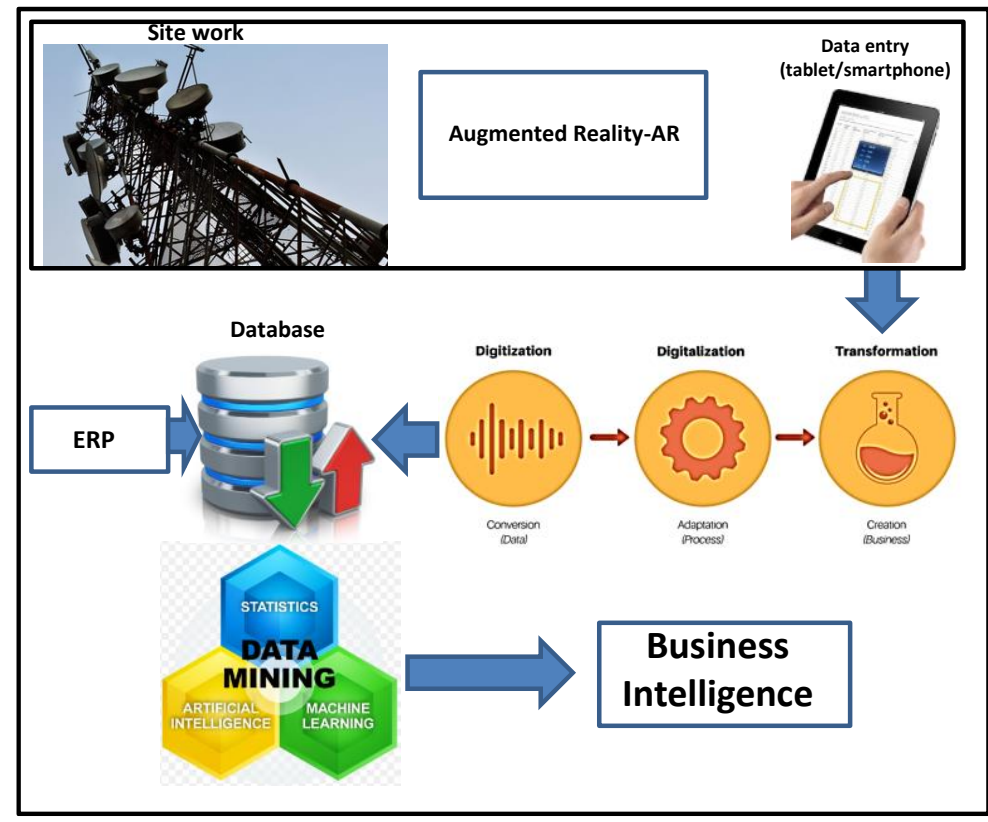

Figure 2. Preliminary functional scheme design of the case of study. 


\section{Upgrade of The Information System AND OF KB Following A RESEARCH APPROACH}

\subsection{Design of Integrated Technologies}

The preliminary specifications of Fig. 2 are matched by the Unified Modeling Language -UMLof Fig. 3, representing the system architecture of the prototype software platform, where:

- the old system is the ERP platform providing data to process (database records of the $\mathrm{KB})$;

- a dynamic Business Process Modeling -BPM- integrating data mining algorithms (Business Process Modeling Mining BPM-M) can process data coming from ERP database and from data entry application (running on a mobile device);

- Smart glasses are interconnected with BPM and with data entry application thus facilitating the execution of working activities and, consecutively, the process optimization.

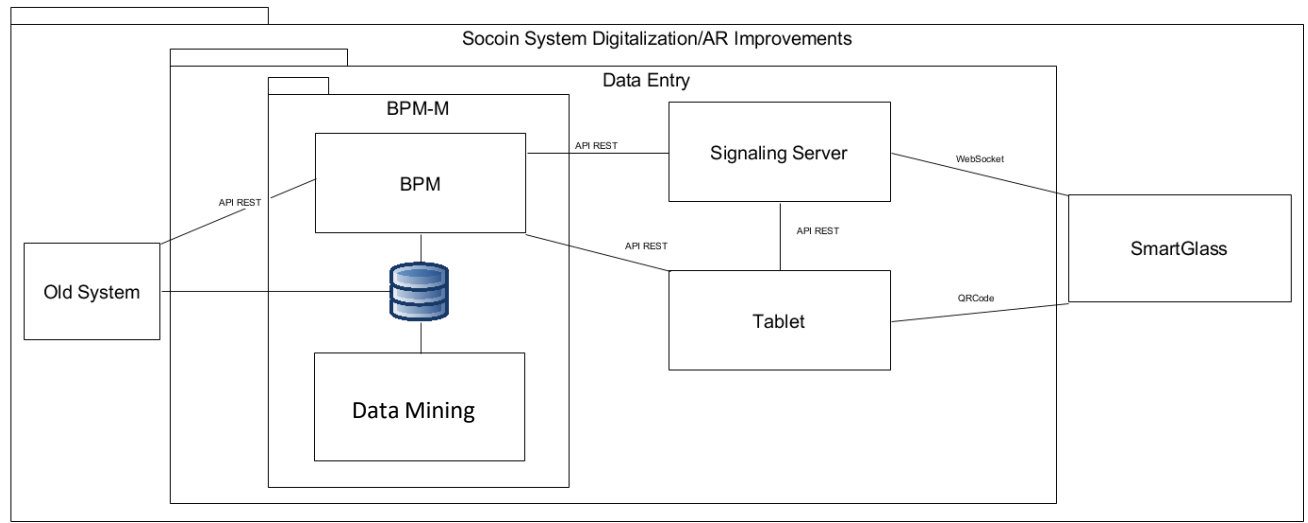

Figure 3. UML schematization if the architecture of Fig.2.

\subsection{Data Mining Uses Cases}

In this section are described the use cases involving data mining engine. The UML diagram (UML2 language) of Fig. 4 defines three main actors involved in the data mining process, which are:

- the system administrator (Admin) which starts the data mining and allows the access to the system database (for example MySql);

- the database system (DB) collecting all data provided by the mobile app enabling digitized data entry;

- the project manager which manages the human resources and working vehicles by using the outputs of the data mining engine able to update human resource key performance indicators -HR KPI-; the data mining outputs facilitate decision making, logistic team coordination and problem solving (the project manager actor can be different in the case for vehicles management and for problems management). 


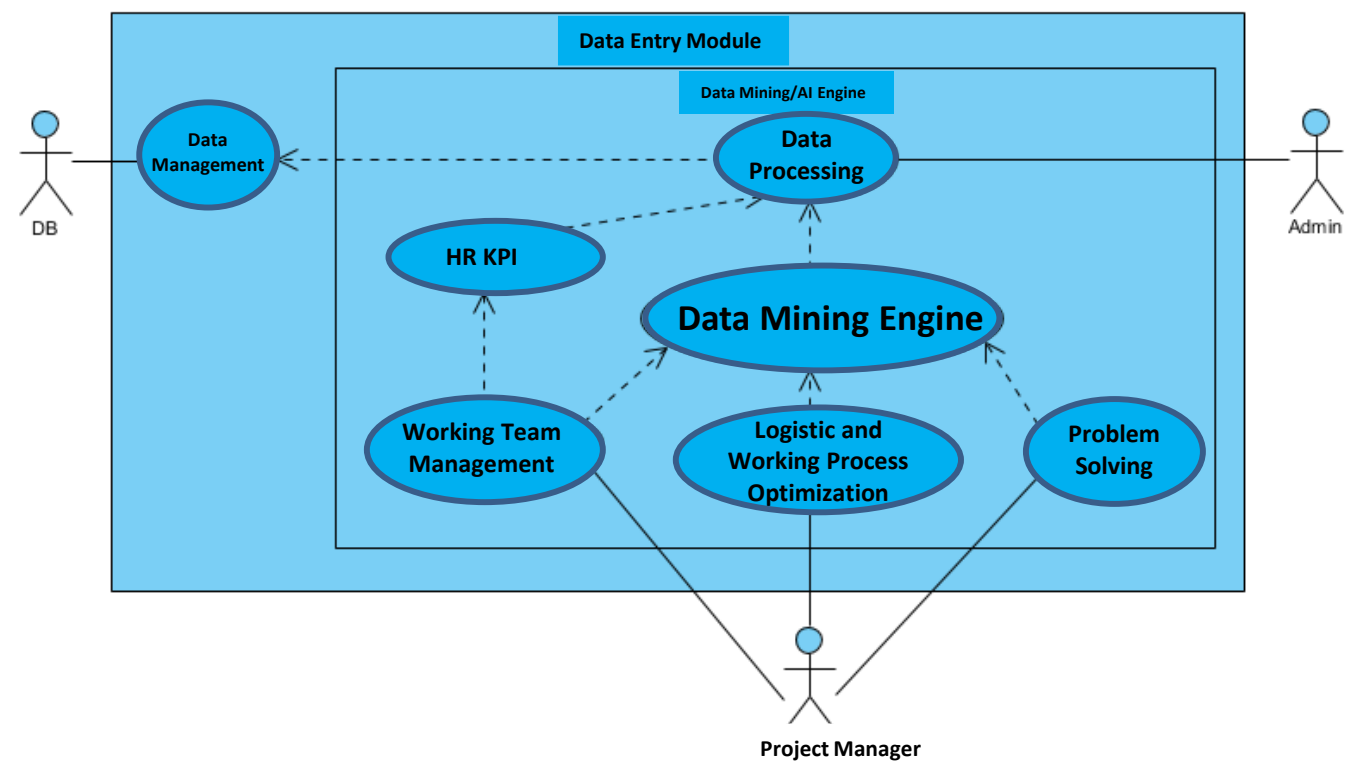

Figure 4. UML2 diagram: use cases of data mining engine.

In the tables reported below are commented the main case uses involving data mining engine which are:

- use case 1: data processing;

- use case 2: HR KPI evaluation;

- use case 3: data mining algorithm application;

- $\quad$ use case 4: working team management;

- use case 5: management optimization of vehicles.

\begin{tabular}{|c|l|}
\hline \multirow{2}{*}{ Description } & $\begin{array}{l}\text { USE CASE 1: DATA PROCESSING } \\
\text { processed by appropriate filters }\end{array}$ \\
\hline Pre-Condition & $\begin{array}{l}\text { The system is ready and Admin starts the data } \\
\text { mining engine }\end{array}$ \\
\hline Post-Condition & $\begin{array}{l}\text { Data are correctly pre-processed and generate } \\
\text { a good output }\end{array}$ \\
\hline Post-Condition & $\begin{array}{l}\text { Data are not correctly pre-processed and } \\
\text { generate a wrong output }\end{array}$ \\
\hline Primary actor & Admin which starts the data processing \\
\hline Basic scenario & $\begin{array}{l}\text { The correct data processing allows to create } \\
\text { good training dataset of data mining models } \\
\text { (predictive and HR KPI models) }\end{array}$ \\
\hline $\begin{array}{c}\text { Alternative } \\
\text { scenario }\end{array}$ & $\begin{array}{l}\text { The data processing did not lead completely } \\
\text { or partially to the expected outputs. Possible } \\
\text { motivations and critical issues are analyzed }\end{array}$ \\
\hline
\end{tabular}




\begin{tabular}{|c|l|}
\hline \multirow{2}{*}{ Description } & $\begin{array}{l}\text { TSE CASE 2: HR KPI EVALUATION } \\
\text { KPI }\end{array}$ \\
\hline Pre-Condition & $\begin{array}{l}\text { The system is working correctly and the } \\
\text { Admin starts the data mining engine }\end{array}$ \\
\hline $\begin{array}{c}\text { Post- } \\
\text { Condition 1 }\end{array}$ & The HR KPI are correctly estimated \\
\hline $\begin{array}{c}\text { Post- } \\
\text { Condition 2 }\end{array}$ & It is impossible to estimate HR KPI \\
\hline Primary actor & Admin which starts the data processing \\
\hline Basic scenario & $\begin{array}{l}\text { The Engine allow to estimate HR KPI and } \\
\text { consecutively the "HR health status" of the } \\
\text { company }\end{array}$ \\
\hline $\begin{array}{c}\text { Alternative } \\
\text { scenario }\end{array}$ & $\begin{array}{l}\text { The HR KPI could not be calculated. One } \\
\text { reason could be the absence of enough data } \\
\text { suitable for the calculation. }\end{array}$ \\
\hline
\end{tabular}

\begin{tabular}{|c|l|}
\hline \multicolumn{2}{|c|}{ USE CASE 3: DATA MINING ALGORITHM A PPLICATION } \\
\hline Description & $\begin{array}{l}\text { The system applies the data mining } \\
\text { techniques using various datasets and } \\
\text { performs classifications and predictions }\end{array}$ \\
\hline Pre-Condition & $\begin{array}{l}\text { The system is working correctly and the } \\
\text { Admin starts the data mining engine }\end{array}$ \\
\hline Post- & $\begin{array}{l}\text { The data mining approaches provide the } \\
\text { expected outputs }\end{array}$ \\
\hline Condition 1 & $\begin{array}{l}\text { It is impossible to apply the defined } \\
\text { techniques correctly }\end{array}$ \\
\hline Pondition 2 & Admin which starts the data processing \\
\hline Basic scenario & $\begin{array}{l}\text { The results are in good matching with } \\
\text { output typologies expected in the design } \\
\text { step }\end{array}$ \\
\hline Alternative & $\begin{array}{l}\text { The identified techniques could not be } \\
\text { applied. One reason could be the absence of } \\
\text { data to process or the insufficient } \\
\text { information }\end{array}$ \\
\hline
\end{tabular}




\begin{tabular}{|c|l|}
\hline \multirow{2}{*}{ Description } & $\begin{array}{l}\text { The project manager assigns the working } \\
\text { team for specific interventions to be carried } \\
\text { out, by analyzing the HR KPI evaluation }\end{array}$ \\
\hline Pre-Condition & $\begin{array}{l}\text { The system is working correctly and the } \\
\text { Admin starts the data mining engine }\end{array}$ \\
\hline $\begin{array}{c}\text { Post- } \\
\text { Condition 1 }\end{array}$ & $\begin{array}{l}\text { The data mining techniques provide } \\
\text { relevant outputs usable to allocate } \\
\text { efficiently human resources for } \\
\text { interventions }\end{array}$ \\
\hline $\begin{array}{c}\text { Post- } \\
\text { Condition 2 }\end{array}$ & $\begin{array}{l}\text { The data mining techniques did not provide } \\
\text { relevant outputs useful for intelligent team } \\
\text { assignment }\end{array}$ \\
\hline Primary actor & $\begin{array}{l}\text { Project Manager } \\
\text { Basic scenario }\end{array}$ \\
& $\begin{array}{l}\text { The project manager analyses the HR KPI } \\
\text { and data mining outputs in order to plan } \\
\text { efficiently the working activities assigning } \\
\text { the correct team }\end{array}$ \\
\hline Alternative & $\begin{array}{l}\text { The project manager is not able to carry out } \\
\text { an optimization of the working processes }\end{array}$ \\
\hline scenario &
\end{tabular}

\begin{tabular}{|c|l|}
\hline \multicolumn{2}{|c|}{ USE CASE 5: MANAGEMENT OPTIMIZATION OF VEHICLES } \\
\hline Description & $\begin{array}{l}\text { The project manager manages efficiently the } \\
\text { working vehicles by analyzing the data mining } \\
\text { outputs }\end{array}$ \\
\hline Pre-Condition & $\begin{array}{l}\text { The system is working correctly and the Admin } \\
\text { starts the data mining engine }\end{array}$ \\
\hline Post-Condition 1 & $\begin{array}{l}\text { The data mining techniques provide relevant } \\
\text { output useful for decision making processes } \\
\text { involving vehicles to assign for specific } \\
\text { interventions }\end{array}$ \\
\hline Post-Condition 2 & $\begin{array}{l}\text { The data mining techniques did not provide } \\
\text { relevant output and the vehicles management } \\
\text { takes place without an intelligent suggestion }\end{array}$ \\
\hline Primary actor & \begin{tabular}{l} 
Project manager managing working vehicles \\
\hline Basic scenario
\end{tabular} \\
& $\begin{array}{l}\text { The project manager enabled to manage working } \\
\text { vehicles can analyze the data mining outputs in } \\
\text { order to plan efficiently the logistic }\end{array}$ \\
\hline Alternative & $\begin{array}{l}\text { The project manager have not enough data and } \\
\text { information in order to optimize the processes } \\
\text { involving vehicles }\end{array}$ \\
\hline
\end{tabular}




\begin{tabular}{|c|c|}
\hline \multicolumn{2}{|c|}{ USE CASE 6: PROBLEM SOLVING } \\
\hline Description & $\begin{array}{l}\text { The project manager in charge } \\
\text { assigned for the management of } \\
\text { problems and critical issues, uses } \\
\text { the decision-making support } \\
\text { provided by the data mining } \\
\text { engine }\end{array}$ \\
\hline $\begin{array}{c}\text { Pre- } \\
\text { Condition }\end{array}$ & $\begin{array}{l}\text { The system is working correctly } \\
\text { and the Admin starts the data } \\
\text { mining engine }\end{array}$ \\
\hline $\begin{array}{c}\text { Post- } \\
\text { Condition } \\
1\end{array}$ & $\begin{array}{l}\text { The techniques provide relevant } \\
\text { outputs for suggestion to the } \\
\text { problem management process }\end{array}$ \\
\hline $\begin{array}{c}\text { Post- } \\
\text { Condition } \\
2\end{array}$ & $\begin{array}{l}\text { The techniques did not provide } \\
\text { relevant output and the } \\
\text { management takes place without } \\
\text { an intelligent suggestion. }\end{array}$ \\
\hline $\begin{array}{l}\text { Primary } \\
\text { actor }\end{array}$ & $\begin{array}{l}\text { Project that manages business } \\
\text { problems. }\end{array}$ \\
\hline $\begin{array}{c}\text { Basic } \\
\text { scenario }\end{array}$ & $\begin{array}{l}\text { The project manager can read the } \\
\text { data mining outputs (for example } \\
\text { risk predictions) in order to solve } \\
\text { correctly problems which can be } \\
\text { classified }\end{array}$ \\
\hline $\begin{array}{l}\text { Alternative } \\
\text { scenario }\end{array}$ & $\begin{array}{l}\text { The project manager is not able to } \\
\text { solve problems because the data } \\
\text { mining outputs are not reliable }\end{array}$ \\
\hline
\end{tabular}

Concerning HR KPI, there are the following 13 basic indicators to consider for a preliminary analysis:

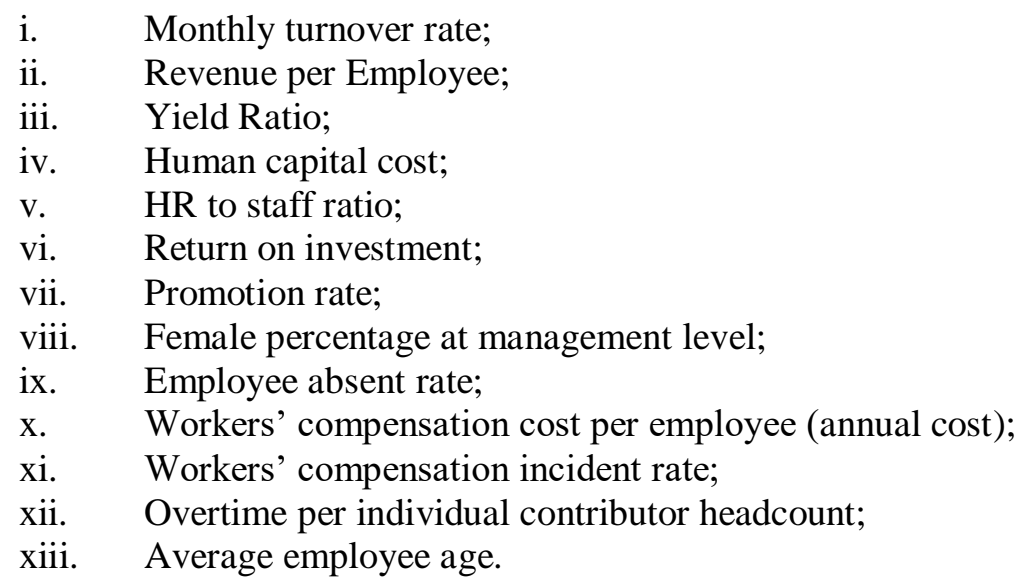

Starting to these indicators it is possible to apply the data mining engine in order to find possible correlations by optimizing the KPI evaluation (advanced KPI evaluation). An approach which can be applied to calculate advance KPI method is to estimate correlation between variables generating a weights vector based on indicator correlations by means of the Pearson's correlation 
coefficient. The correlation algorithm calculates this coefficient which is the covariance of the two variables divided by the product of their standard deviations [23]-[24]:

$$
\rho_{X, Y}=\frac{\operatorname{cov}(X, Y)}{\sigma_{X} \sigma_{Y}}
$$

For the other typologies of data mining outputs can be adopted the following algorithms/approaches:

- $\quad$ K-nearest neighbors -KNN- (classifier);

- eXtreame Gradient Boosting -XGBOOST- (prediction);

- logistic regression;

- $\quad$ Random forest (classifier);

- $\quad$ Classification And Regression Trees for Machine Learning -CART-;

- K-Means (data clustering);

- Artificial Neural Network (prediction).

In Fig. 5 is illustrated the sequence diagram describing the timing of all the data mining cases use.

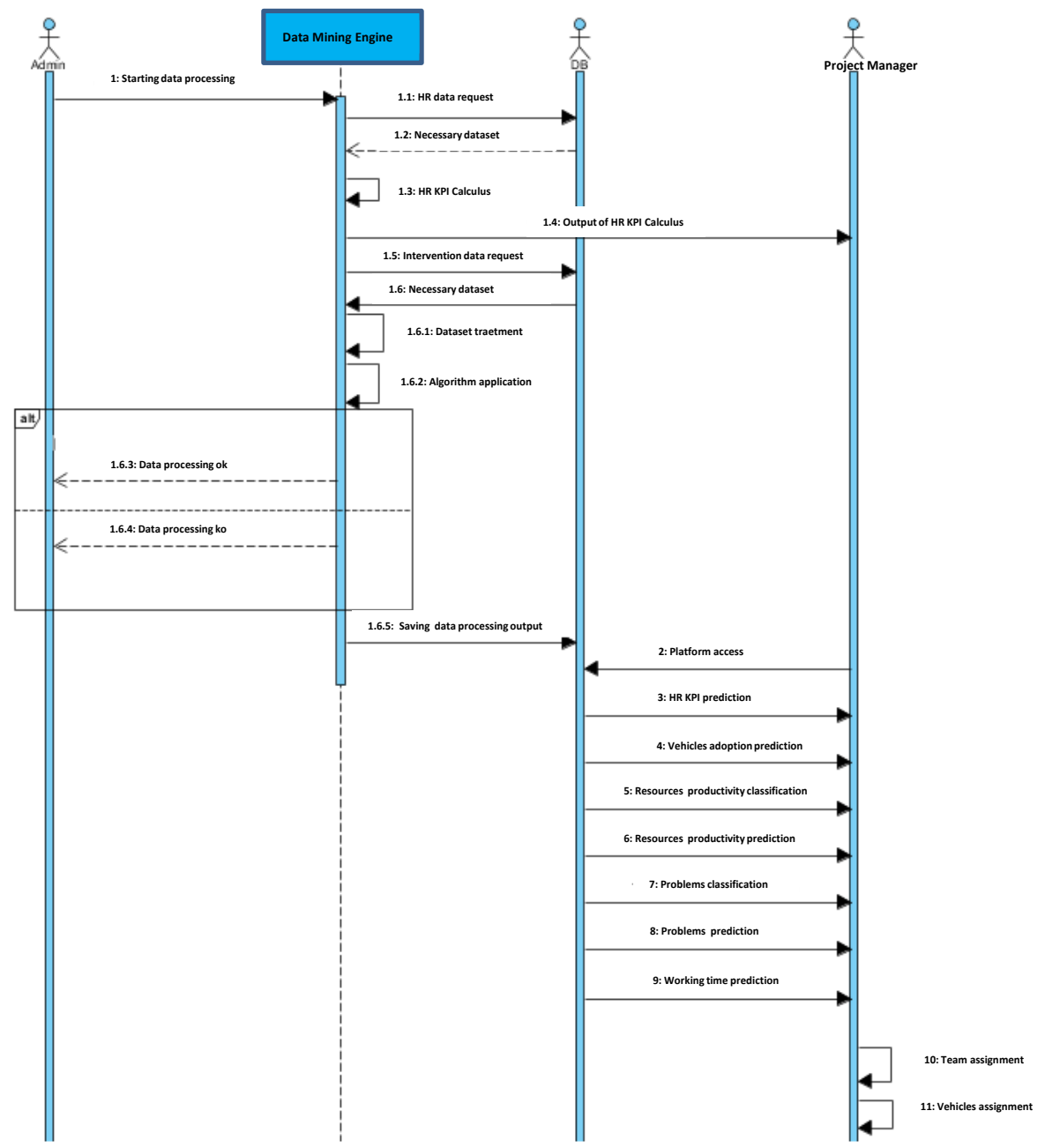

Figure 5. UML sequence diagram representing cases use of data mining engine. 


\section{DATA ENTRY AR FACILITIES}

In this section is commented the Android application enabling data entry, augmented reality and online remote communication through a web App. The Android software consists of an integrated software-hardware having the following specifications:

- to support workers during operations and for the use of various tools by means of a "virtually present" supervisor (external expert);

- to aid for tracking and recording working processes.

The Android software combines the augmented reality with the hands-free functionality, making interventions faster and more efficient. The worker wearing a smartglass will be able to communicate with an external expert receiving information on how to operate. The expert could use smartphones, tablets or PCs having a compatible browsers thus communicating and observing in real time what the worker sees on site. The expert will interact with the operator through:

- audio instructions;

- video and text chat;

- screenshots of video chat, possibly modified within the integrated system (interactive/augmented function);

- links to images on the web.

In Fig. 6 is illustrated the main mockup of the Android app reporting the following fields:

-Field A (working site): once you have clicked on the site's title, you will be able to access a summary screen showing all the sections and information relating to the construction site (info and notes, map how to get there, activity, video documentation, guides and guides);

-Field B: activity of the working site (main field grouping B1,B2,B3 and B4);

-Field B1: this field indicates the human resources which are in the working site (data entry and verification functions);

-Field B2 (activity execution): this field enables geo-referenced photos, it allows to view and to update the list of technical safety checks to be carried out at each site before the start of the works and at the closing, allows to view the operating procedures, allow to view the operation checklist for the closure of the working site;

-Field B3 (material verification and update): by this field the project manager will be able to manage and to control the materials both at the entrance to the site and at the exit (loading / unloading), and when the material is not used or it is disposed or it is returned to the warehouse;

-Field B4 (vehicles detection): by this field the project manager will be able to write a report about the vehicles daily adopted for the working site, about loading processes, and about driver association;

-Field C (georeferenced map): by GPS it is possible to see and to assign the working site localization (aspect useful for logistic); 
-Field D (information and notes): by this field the user will view all the information associated with the working site (site name, any descriptions and notes supporting the work team, traffic information, useful addresses and contact information);

-Field E (documentation): by this field the project manager will view the technical documents;

-Field F (video): manual to acquire video by smartglasses;

-Field G (manual): manual for other functions of the smartglasses;

-Field $\mathrm{H}$ (procedures): procedures to configure the Vuzix smartglasses (see example shown in Fig. 7).

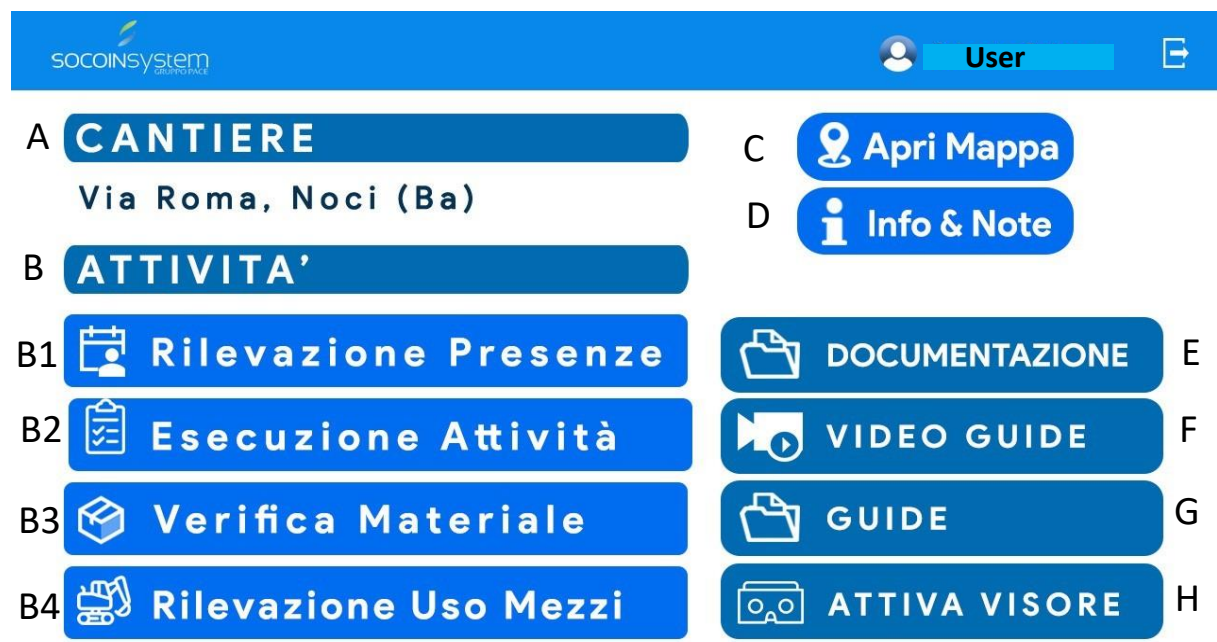

Figure 6. UML sequence diagram representing cases use of data mining engine.

socolnsystem $\quad 8 \longdiv { \square }$
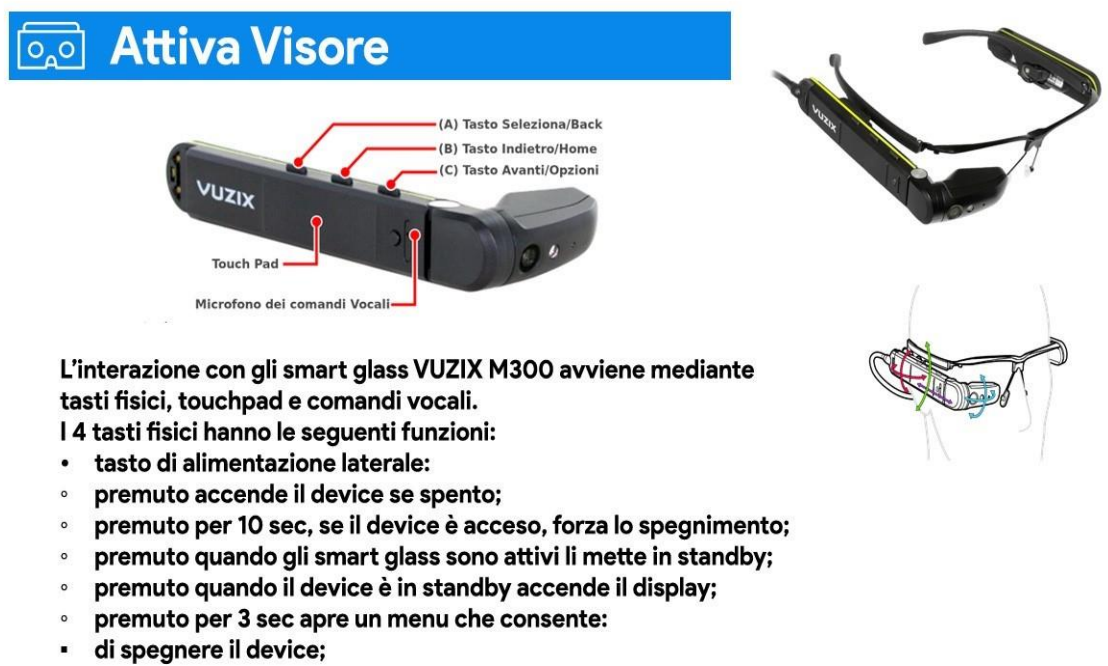

L'interazione con gli smart glass VUZIX M300 avviene mediante tasti fisici, touchpad e comandi vocali.

I 4 tasti fisici hanno le seguenti funzioni:

- tasto di alimentazione laterale:

premuto accende il device se spento;

premuto per $10 \mathrm{sec}$, se il device è acceso, forza lo spegnimento;

premuto quando gli smart glass sono attivi li mette in standby;

- premuto quando il device è in standby accende il display;

- premuto per $3 \mathrm{sec}$ apre un menu che consente:

- di spegnere il device;

Figure 7. Example of procedures to configure the Vuzix smart glasses.

The interactive function improved by the smartglass is described by the following use case: 


\begin{tabular}{|c|l|}
\hline \multirow{2}{*}{ Description } & \multicolumn{1}{|l|}{$\begin{array}{l}\text { USE CASE 7: AR INTERACTIVITY } \\
\text { sees in real time the working site and listens the } \\
\text { worker which are performing an activity }\end{array}$} \\
\hline Pre-Condition & $\begin{array}{l}\text { The worker wear the smart glass and requires a } \\
\text { call with the expert in order to execute a specific } \\
\text { activity }\end{array}$ \\
\hline Post-Condition 1 & $\begin{array}{l}\text { The expert speaks and listens in real time giving } \\
\text { voice suggestions remotely }\end{array}$ \\
\hline Post-Condition 2 & $\begin{array}{l}\text { The expert speaks and listens in real time with the } \\
\text { worker by highlighting on the screen some region } \\
\text { (with a pencil tool marking a specific area). The } \\
\text { worker sees the marker on his smart glass and can } \\
\text { operate correctly }\end{array}$ \\
\hline Primary actor & \begin{tabular}{l} 
Worker (human resource) \\
\hline Basic scenario \\
Alternative \\
scenario
\end{tabular} \\
\hline & $\begin{array}{l}\text { The worker is in the working site and wears the } \\
\text { order to learn its functions (by means of the } \\
\text { Android App) }\end{array}$ \\
\hline
\end{tabular}

\section{CONCLUSION}

The goal of the paper is to show design results of a case of study regarding research and development $-R \& D$ - applied on the reengineering of production processes. In particular has been analysed an industry project enhancing the difference between $\mathrm{KB}$ and $\mathrm{KG}$, where the $\mathrm{KB}$ is necessary to improve the actual production processes, and $\mathrm{KG}$ is fundamental for process optimization. Starting to the 'AS IS' mapping processes, the paper deals the design of specifications enabling KG by data mining, data entry application and AR technology. The attention is focused on data mining uses cases and on smartglass technology. In order to furthermore speed up data flow and data process, data mining and AR can be implemented with Standard Extract, Transform, Load (ETL) procedures and with Robotic Process Automation (RPA) tools for digitization. The proposed paper is related to preliminary results concerning the project specifications formulation and the architecture design, describing all elements of the proposed technology, and all the steps necessary to formulate the R\&D research project. In table are summarized all the limits and the advantages of all the elements discussed in the work. 
Table 1. Limits and advantages of technologies and elements considered into the project.

\begin{tabular}{|c|c|c|c|}
\hline Technology/elements & $\begin{array}{l}\text { Knowledge type } \\
\text { (KB: Knowledge } \\
\text { Base; KG: } \\
\text { Knowledge Gain) }\end{array}$ & Limits & Advantages \\
\hline Process Mapping & $\begin{array}{l}\text { KB the "AS IS" } \\
\text { processes } \\
\text { mapped through } \\
\text { Arise press tool, and } \\
\text { data are registered } \\
\text { into a database -DB- } \\
\text { ) }\end{array}$ & $\begin{array}{l}\text { The process } \\
\text { mapping } \\
\text { requires a full } \\
\text { time } \\
\text { collaboration } \\
\text { between } \\
\text { researchers and } \\
\text { industry human } \\
\text { resources }\end{array}$ & $\begin{array}{l}\text { The 'AS IS' } \\
\text { process } \\
\text { mapping is } \\
\text { necessary to } \\
\text { design the new } \\
\text { platform } \\
\text { improving KG }\end{array}$ \\
\hline ERP database & $\begin{array}{l}\text { KB (the ERP digital } \\
\text { information is } \\
\text { necessary for data } \\
\text { mining processing } \\
\text { providing a DB-) }\end{array}$ & $\begin{array}{l}\text { Possibility to } \\
\text { integrate and to } \\
\text { interconnect the } \\
\text { new platform } \\
\text { enabling ERP } \\
\text { data transfer } \\
\text { automatism }\end{array}$ & $\begin{array}{l}\text { Availability of a } \\
\text { unique software } \\
\text { platform } \\
\text { enabling KG }\end{array}$ \\
\hline BPM & KB & $\begin{array}{l}\text { The classic BPM } \\
\text { The BPM allows } \\
\text { to map statically } \\
\text { the production } \\
\text { processes }\end{array}$ & $\begin{array}{l}\text { Digital mapping } \\
\text { of processes }\end{array}$ \\
\hline BPM-M- & $\overline{K G}$ & $\begin{array}{l}\text { The data mining } \\
\text { integration into } \\
\text { the BPM allows } \\
\text { to map } \\
\text { dynamically the } \\
\text { production } \\
\text { processes } \\
\text { (process mining) }\end{array}$ & $\begin{array}{l}\text { Synchronization } \\
\text { between data } \\
\text { mining } \\
\text { algorithms and } \\
\text { processes in } \\
\text { progress }\end{array}$ \\
\hline Data entry APP & KB & $\begin{array}{l}\text { Updating of data } \\
\text { transfer into } \\
\text { database } \\
\text { (capillary use of } \\
\text { different } \\
\text { smartglasses) }\end{array}$ & $\begin{array}{l}\text { Speed up of the } \\
\text { process } \\
\text { mapping and } \\
\text { enabling data } \\
\text { mining } \\
\text { processing. } \\
\text { information } \\
\text { digitization } \\
\text { processes }\end{array}$ \\
\hline
\end{tabular}




\begin{tabular}{|c|c|c|c|}
\hline Smartglass & $\overline{K G}$ & $\begin{array}{l}\text { Technology } \\
\text { transfer } \\
\text { necessary }\end{array}$ & $\begin{array}{l}\text { Speeding up of } \\
\text { operations in } \\
\text { the working } \\
\text { site. } \\
\text { Interactivity } \\
\text { (augmented } \\
\text { reality) with } \\
\text { marker } \\
\text { enhancing on } \\
\text { the smartglass } \\
\text { screen } \\
\text { particular action } \\
\text { to perform }\end{array}$ \\
\hline Data Mining & $\mathrm{KG}$ & $\begin{array}{l}\text { Results } \\
\text { reliability. Good } \\
\text { construction of a } \\
\text { training dataset } \\
\text { model. } \\
\text { Technology } \\
\text { transfer } \\
\text { necessary }\end{array}$ & $\begin{array}{lr}\text { Data } & \text { mining } \\
\text { enables } & \text { BI } \\
\text { processes } & \end{array}$ \\
\hline
\end{tabular}

Data processing by data mining algorithms and AR testing results will be presented in other works after a validating processes according with industry verification.

\section{APPENDIX}

In this section are illustrated two examples of workflows improving industry KB by "AS IS" process mapping. The proposed flowcharts have been formulated by Arise press tool [25] by adopting the symbols of Fig. 8. The first mapped process (Fig. 9) is related to human resource control by means of a digitized register, and the second mapped process (Fig. 10) is related to vehicle control (vehicle to use in the working site).

$\begin{array}{lll}\square_{\square} \text { Connection } & \square \text { Event } & \text { Activity } \\ \oplus \text { AND rule } & \text { xoR rule } & \text { OR rule } \\ \square \text { Organizational unit } & \square \text { Role } & \square \text { Database } \\ \square \text { Location } & \square \text { Entity } \\ \square \text { Document } & \square \text { IT system } \\ \square \text { Risk } & \square \text { Process interface }\end{array}$

Figure 8. Symbols adopted for process mapping. 
International Journal of Data Mining \& Knowledge Management Process (IJDKP) Vol.9, No.5, September 2019

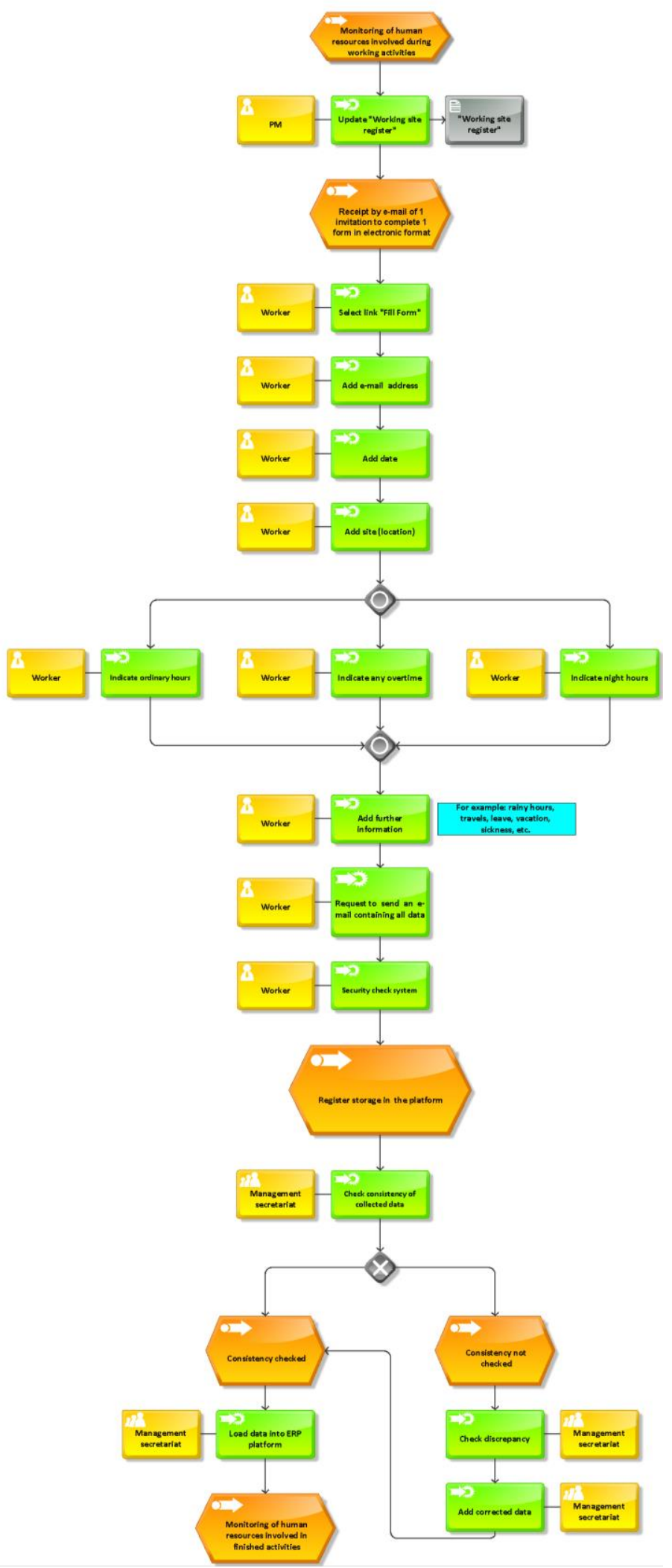

Figure 9. Sub-process related the human resources control (digitized register). 


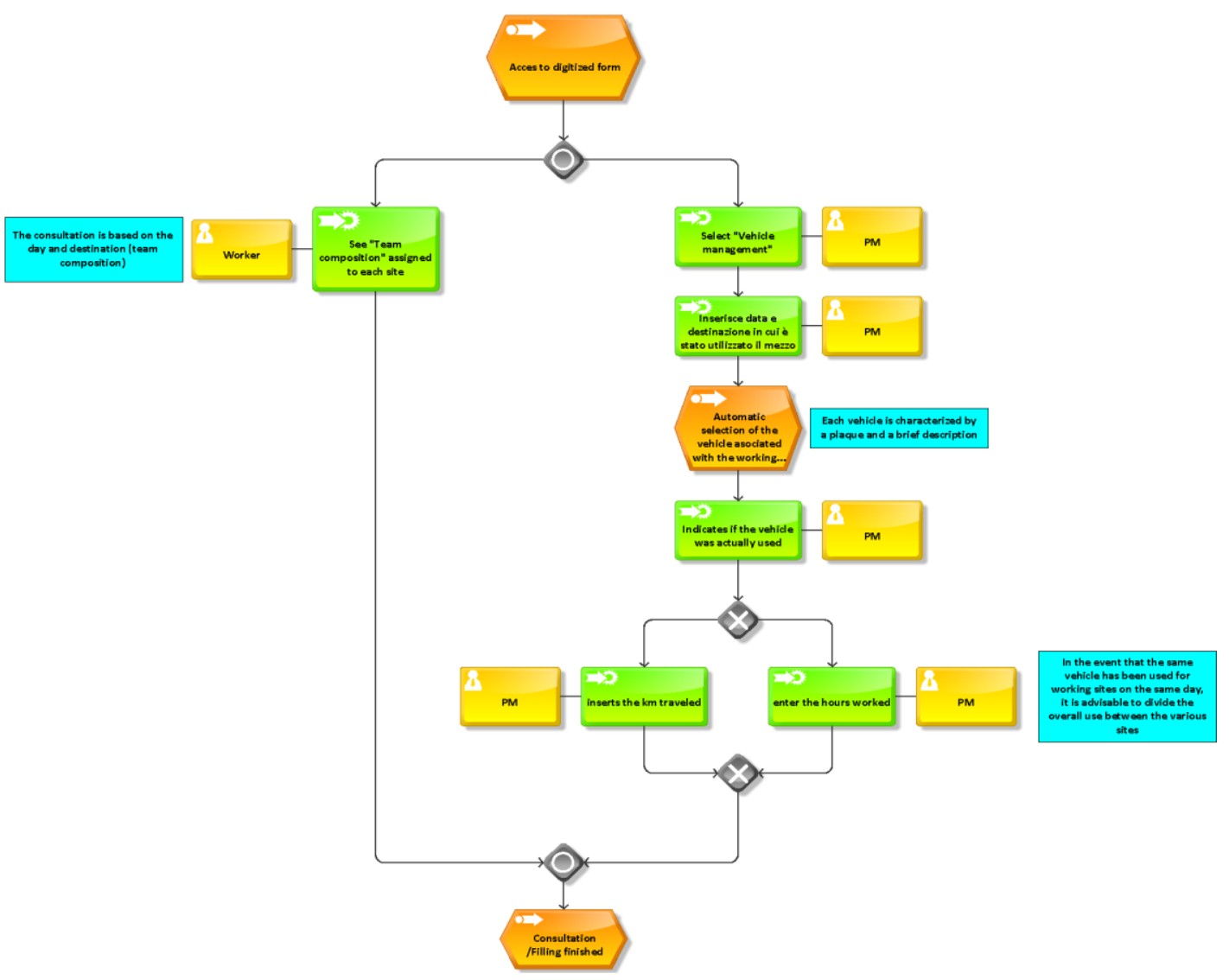

Figure 10. Flow chart representing vehicle control sub-process.

\section{ACKNOWLEDGEMENTS}

The work has been developed in the frameworks of the Italian projects: "Ingegnerizzazione di processo di digitalizzazione / elaborazione dei dati e di procedure di operatività mediante realtà aumentata: SOCOIN SYSTEM DIGITALIZATION / AR IMPROVEMENTS" [Process engineering of digitization / data processing and of operation procedures through increased reality: SOCOIN SYSTEM DIGITALIZATION / AR IMPROVEMENTS]. The authors would like to thank the following researchers and collaborators: G. Birardi, B. Boussahel, V. Calati, D. Carella, A. Colonna, D. Convertini, R. Cosmo, F. De Carlo, E. De Fonte, R. Guglielmi, M. Legrottaglie, A. Leogrande, A. Lombardi, A. Lorusso, L. Maffei, S. Maggio, N. Malfettone, S. F. Massari, D. monopoli, L. Patruno, L. Pellicani, D. Ria, D. D. Romagno, P. Scagliusi, D. Suma, F. Tarulli, E. Valenzano, and V. Vitti. 


\section{REFERENCES}

[1] Bandi, S., Angadi, M. \& Shivarama, J. (2015) "Best Pratices in Digitasation: Planning and Workflow Processes", Emerging Technologies and Future of Libraries: Issues and Challenges, ch. 33, pp. 332339 http://eprints.rclis.org/24577/1/Digitization\%20ETFL-2015.pdf

[2] O’Hara, J. \& Higgins, J. (2010) "Human-system Interfaces for Automatic Systems", Seventh American Nuclear Society International Topical Meeting on Nuclear Plant Instrumentation, Control and Human-Machine Interface Technologies (NPIC \&HMIT 2010) https://www.bnl.gov/isd/documents/74159.pdf.

[3] Alter, S. (2008) "Defining Information Systems as Work Systems: Implications for the IS Field", Business Analytics and Information Systems. Paper 22. http://repository.usfca.edu/at/22

[4] Lin, S., Gao, J., Koronios, A. \& Chanana, V. (2007) "Developing a Data Quality Framework for Asset Management in Engineering Organisations”, International Journal Information Quality, Vol. 1, No. 1, pp. 100-126.

[5] Kekwaletswe, R. M. \& Lesole, T. (2016) “A Framework for Improving Business Intelligence through Master Data Management”, Journal of South African Business Research, Vol. 2016, No. 473749, pp. $1-12$.

[6] Parviainen, P. \& al. (2017) "Tackling the Digitalization Challenge: How to Benefit from Digitalization in Practice", International Journal of Information Systems and Project Management, Vol. 5, No. 1, pp. 63-77.

[7] Bley, K., Leyh, C. \& Schäffer, T. (2016) "Digitization of German Enterprises in the Production Sector: Do they Know How "Digitized" they are?", Proceeding of 22nd Americas Conference on Information Systems - AMCIS 2016At: San Diego, USA, August 2016.

[8] Report (2015) "Think Act Beyond Mainstream: Building Europe's road "Construction 4.0"Digitization in the construction industry", ROLAND BERGER GMBH.

[9] Sindhu, D. \& Sangwan, A. (2017) “Optimization of Business Intelligence using Data Digitalization and Various Data Mining Techniques”, International Journal of Computational Intelligence Research, Vol. 13, No. 8, pp. 1991-1997.

[10] Matt, C., Hess, T. \& Benlian, A. (2015) "Digital Transformation Strategies", Business and Information Systems Engineering, Vol. 57, No.5, pp. 339-343.

[11] IBM Global Business Services, Executive Report (2011) "Digital transformation Creating new Business Models where Digital Meets Physical”, https://s3-us-west2.amazonaws.com/itworldcanada/archive/Themes/Hubs/Brainstorm/digital-transformation.pdf

[12] Muhammad, G., Ibrahim, J., Bhatti, Z., Waqas, A. (2014) "Business Intelligence as a Knowledge Management Tool in Providing Financial Consultancy Services", American Journal of Information System, Vol. 2, No. 2, pp. 26-32.

[13] Shehzad, R. \& Khan, M. N. A. (2013) "Integrating Knowledge Management with Business Intelligence Processes for Enhanced Organizational Learning”, International Journal of Software Engineering and Its Applications, Vol. 7, No. 2, pp. 83-92.

[14] Wang, H. \& Wang, S. (2008) "A Knowledge Management Approach to Data Mining Process for Business Intelligence”, Industrial Management \& Data Systems, Vol. 108, No. 5, pp. 622-634.

[15] Bara, A., Botha, I., Diaconiţa, V., Lungu, I., Velicanu, A., Velicanu, M. (2009) “A Model for Business Intelligence Systems’ Development”, Informatica Economică, Vol. 13, No. 4, pp. 99-108. 
[16] Guarda, T., Santos, M., Pinto, F., Augusto, M. \& Silva, C. (2013) "Business Intelligence as a Competitive Advantage for SMEs", International Journal of Trade, Economics and Finance, Vol. 4, No. 4, pp. 187-190.

[17] Zhu, E., Lilienthal, A., Shluzas, L. A., Masiello, I. \& Zary, N. (2015) “Design of Mobile Augmented Reality in Health Care Education: A Theory-Driven Framework”, JMIR Medical Education, Vol.1, No. 2, pp. 1-10.

[18] Mekni, M. \& Lemieux, A. (2014) “Augmented Reality: Applications, Challenges and Future Trends", Applied Computational Science, pp. 255-214.

[19] Gutiérrez, J. M., Mora, C. E., Díaz, B. A. \& Marrero, A. G. (2017) "Virtual Technologies Trends in Education”, EURASIA Journal of Mathematics Science and Technology Education, Vol. 13, No. 2, pp.469-486.

[20] Frascati Manual 2015: The Measurement of Scientific, Technological and Innovation Activities Guidelines for Collecting and Reporting Data on Research and Experimental Development. OECD (2015), ISBN 978-926423901-2 (PDF).

[21] Massaro, A., Vitti, V., Lisco, P., Galiano, A. \& Savino, N. (2019) “A Business Intelligence Platform Implemented in a Big Data System Embedding Data Mining: a Case of Study", International Journal of Data Mining \& Knowledge Management Process (IJDKP), Vol.9, No.1, pp. 1-20.

[22] Massaro, A., Lisco, P., Lombardi, A., Galiano, A. \& Savino N. (2019) "A Case Study of Research Improvements in an Service Industry Upgrading the Knowledge Base of the Information System and the Process Management: Data Flow Automation, Association Rules and Data Mining”, International Journal of Artificial Intelligence and Applications (IJAIA), Vol. 10, No. 1, pp. 25-46.

[23] Massaro, A., Meuli, G. \& Galiano, A. (2018) “Intelligent Electrical Multi Outlets Controlled and Activated by a Data Mining Engine oriented to Building Electrical Management", International Journal on Soft Computing, Artificial Intelligence and Applications (IJSCAI), Vol. 7, No.4, pp. 1-20.

[24] Myers, J. L. \& Well, A. D. Research Design and Statistical Analysis. Lawrence Erlbaum (2nd ed.) 2003.

[25] Grzegorz, J. \& Bartosz, A, (2015) “The Use of IT TOOLD for th e Simulations of Economic Processes”, Information Systems in Management, Vol . 4, No. 2, pp. 87-98.

\section{AUTHOR}

Alessandro Massaro: Research \& Development Chief of Dyrecta Lab s.r.l.

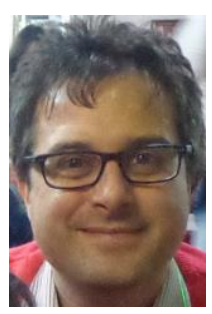

